\title{
Organic matter of fossil origin in the amberine speleothems from E1 Soplao Cave (Cantabria, Northern Spain)
}

\author{
Fernando Gázquez ${ }^{1}$, José-María Calaforra ${ }^{*}$, Fernando Rull ${ }^{2}$, Paolo Forti ${ }^{3}$, and Antonio \\ García-Casco ${ }^{4}$
}

\begin{abstract}
:
Gázquez F., Calaforra J.-M., Rull F., Forti P. and García-Casco A. 2012. Organic matter of fossil origin in the amberine speleothems from EI Soplao Cave (Cantabria, Northern Spain). International Journal of Speleology, 41(1), 113-123. Tampa, FL (USA). ISSN 03926672. DOI: http://dx.doi.org/10.5038/1827-806X.41.1.12

Unusual amberine-coloured speleothems were recently found in El Soplao Cave (Cantabria, Spain). Chromophore elements such as $\mathrm{Fe}, \mathrm{Mn}, \mathrm{Cd}$, Co or Ti were not present in significant quantities. Rather, our data show that their colour comes from leachates of fossilized organic material hosted in the carbonaceous Urgonian facies of the host rock. These leachates are related to the Cretaceous amber deposit that has been recently discovered in the vicinity of El Soplao Cave. The presence of humic and fulvic acids of fossil origin were confirmed by IR and Raman spectroscopic analysis of the carbonaceous strata and the speleothems. In addition, the mineralogy of the amberine speleothems was studied. Alternating bands made of calcite and aragonite reveal that periods of humidity and aridity occurred within the cave during the speleothem genesis.
\end{abstract}

Keywords: speleothems; infrared spectroscopy; organic matter; Raman spectroscopy; El Soplao Cave

Received 14 November 2011; Revised 18 December 2011; Accepted 21 December 2011

\section{INTRODUCTION}

The presence of organic compounds within speleothems has revealed a new pool of climate proxies based on cave sediments (Baker et al., 1993; Baker et al., 1996; McGarry \& Baker, 2000; van Beynen et al., 2001). Earlier work in this field suggested that differences in the colouration of bands within the speleothems could be due to variations in the amount of organic content (Caldwell et al., 1982). Attention was also focussed on fluorescence and luminescence of organic compounds in speleothems and their possible application as a palaeoclimate proxy (Baker

${ }^{1}$ Water Resources and Environmental Geology Research Group - Dept. of Hydrogeology and Analytical Chemistry - University of Almería, Crta.Sacramento s/n, 04120 La Cañada de San Urbano, Almeria. (f.gazquez@ual.es) (*jmcalaforra@ual.es)

${ }^{2}$ Unidad Asociada UVA-CSIC al Centro de Astrobiología, University of Valladolid. Parque tecnológico Boecillo, 47151. Valladolid (Spain) (rull@fmc.uva.es)

${ }^{3}$ Italian Institute of Speleology - Dept. of Earth and GeologicalEnvironmental Sciences, Via Zamboni 67, 40126 Bologna (Italia) (paolo.forti@unibo.it)

${ }^{4}$ Dept. of Mineralogy and Petrology - Instituto Andaluz de Ciencias de la Tierra, University of Granada-CSIC, Fuentenueva s/n.18002, Granada. (agcasco@ugr.es) et al., 1993; Shopov et al., 1994; Baker et al., 1996; White, 1997; van Beynen et al., 2001; Shopov, 2004; Crowell \& White, 2012).

Recently, biological compounds found in speleothems have been used as biomarkers of biological activity in soils overlying caves (Xie et al., 2003; Blyth et al., $2007,2008)$; in some cases this has provided a record of anthropic activities on the surface and even of fires (Perrette et al., 2008).

Traditionally, the abundance of organic compounds in speleothems has been related to leachates from the soil profile overlying the cave. Some studies identified these compounds as fulvic and humic acids, similar to those found in coral skeletons and carbonaceous marine sediments (Ramseyer et al., 1997).

In terms of the origin of organic compounds in speleothems, Blyth et al. (2008) suggested four potential sources: (1) aerial transport, which usually leads to the incorporation of pollen and spores, (2) transport of soil or host rock components dissolved in the cave drip water, (3) incorporation of organic material derived from subterranean fauna, (4) and production of organic compounds in situ related to biofilms.

Current investigations are also focussed on the transport of organic matter in karstic water and colloidal transport of inorganic ions linked to organic 
molecules, such as fulvic and humic acids from the overlying soil (Lead \& Wilkinson, 2006; Fairchild \& Hartland, 2010). Nevertheless, no work has yet identified the carbonaceous strata of the host rock as the main/only source of organic compounds.

The subject of the present paper is to describe and to identify the origin of the rare dark colour in recently-found amberine-coloured speleothems in $\mathrm{El}$ Soplao Cave (northern Spain). Due to their unusual coloration, the cave guides termed these speleothems "amberine stalactites and stalagmites" (Gázquez et al., 2010). The chromophore features that give colour to the amberine speleothems were identified by Raman and infrared spectroscopy. We also analyzed the mineralogy of these rare speleothems, made of alternating layers of calcite and aragonite in order to be able to describe the palaeoenvironmental evolution in El Soplao Cave over the genesis period of the amberine speleothems.

\section{Geological setting}

El Soplao Cave $\left(43^{\circ} 17^{\circ} 45,42 ” N\right.$ - 4²5`45, 76”W) is located in the Sierra de Arnero, in the Escudo de Cabuérniga mountain range (Cantabria, Northern Spain). The Sierra de Arnero mountain chain runs parallel to the Cantabrian Coast, between the Bustriguado and Nansa valleys (municipal districts of Valdáliga, Rionansa and Herrerías) (Fig. 1).

The cave entrance is $540 \mathrm{~m}$ a.s.1. and extends over $15 \mathrm{~km}$, with barely 50 metres variation in altitude. The total length of the cave, including the mining galleries, is approximately $20 \mathrm{~km}$. New galleries have recently
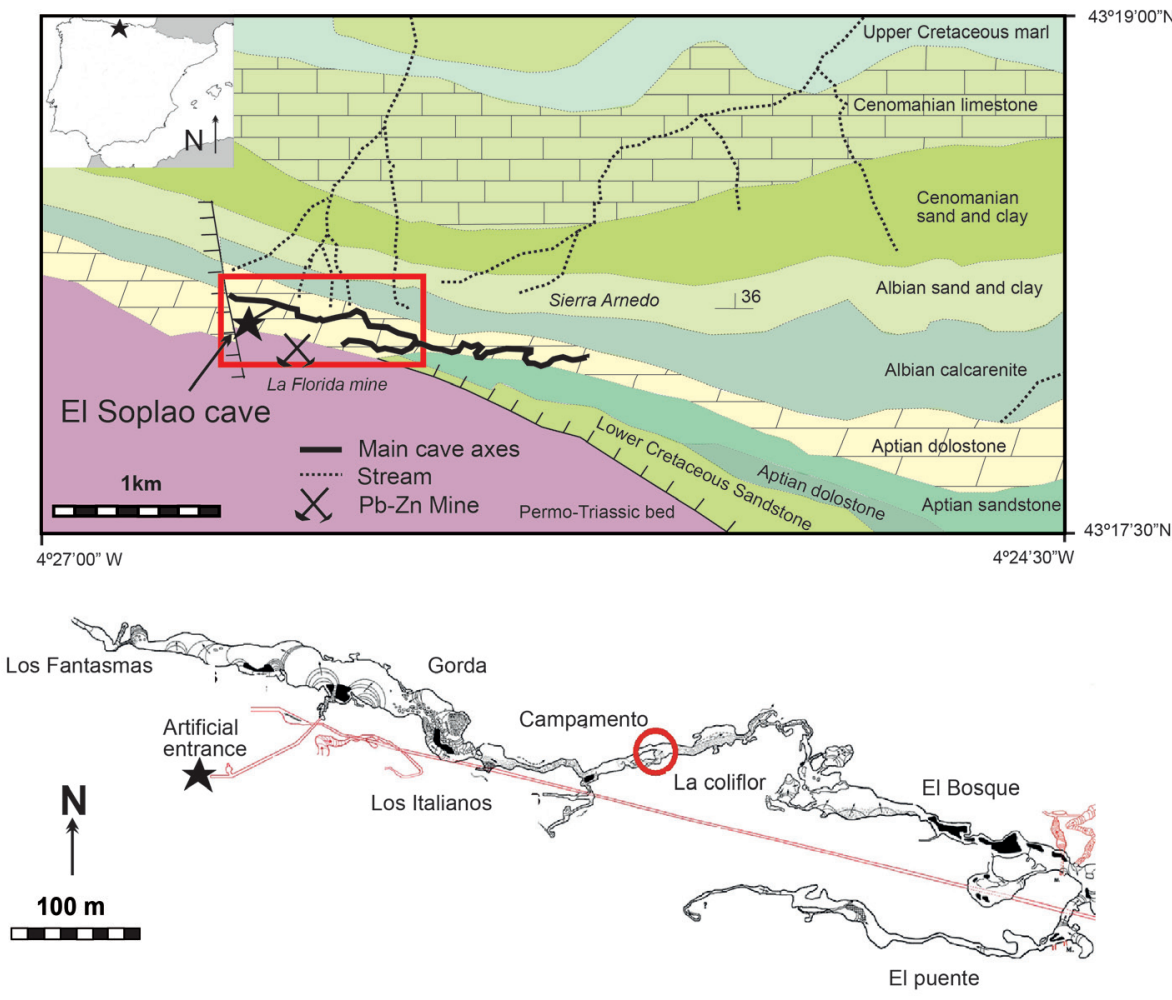

Figure 1. Location and geological setting of El Soplao Cave, and a plan view of part of the cave. The circle shows the location of the amberine speleothem formation. Cartography modified from IGME (1976); cave topography courtesy of EI Soplao S.L. been discovered fact that significantly increases the known development of the cave. The cave passages are oriented mainly NW-SE, with a secondary axis along NE-SW. An artificial cave mouth excavated parallel to the Isidra gallery serves as entrance for touristic visits. In addition, there are two natural cave entrances: Torca Ancha and Torca Juñosa, but access is difficult. Preliminary studies (unpublished data) inside and outside the cave suggest other entrances may exist, which influence the microclimate dynamics and cave environment. El Soplao Cave was opened as a show cave in 2005 .

The cave is excavated in the Florida Formation, a shallow platform carbonate rocks of Early Cretaceous (Aptian) age. Important deposits of lead and zinc sulphides occur in the Florida Mine and in the El Soplao Cave itself (Quesada et al., 2005; LópezCilla et al., 2009; López-Horgue et al., 2009). The stratigraphic sequence indicates levels of fossilized organic material of Lower Cretaceous age (Urgonian facies) as well as fusinites related to the burning of Cretaceous forests (Menor-Salván et al., 2010). Around El Soplao Cave, an amber deposit related to those strata and containing abundant bioinclusions has been recently discovered (Najarro et al., 2009).

\section{MATERIALS AND METHODS}

\section{Sample description and sample pre-treatment}

Representative samples of broken amberine speleothems (Fig. 2A) and carbonaceous Urgonian strata were taken from El Soplao Cave (Fig. 2B). The criterion for selecting samples of speleothems was based on colour, taking only those of darker colour.

Sample SPLAMB-01 is a dark, strongly coloured stalactite fragment, almost black in colour; this colouration is an unusual characteristic for this type of speleothem, especially when compared to the whitish aragonite speleothems that coat the galleries of the cave (Gázquez et al., 2011). The central feeding canal that is characteristic of stalactites was perfectly conserved and there were no signs of recrystallization. The outer layers consist of powdery calcite lamina (Fig. 2C).

Sample SPLAMB-02 is a fragment of an amberine stalactite cut longitudinally, perpendicular to its growth axis (Fig. 2D). Its mineralogy is based on alternating layers of calcite and aragonite, confirmed by Raman and IR spectroscopy. The sample preserves the central feeding canal and the outer layers have a whitish colour, similar to sample SPLAMB-01. Sample SPLAMB-03 is a stalactite $20 \mathrm{~cm}$ in length; the 

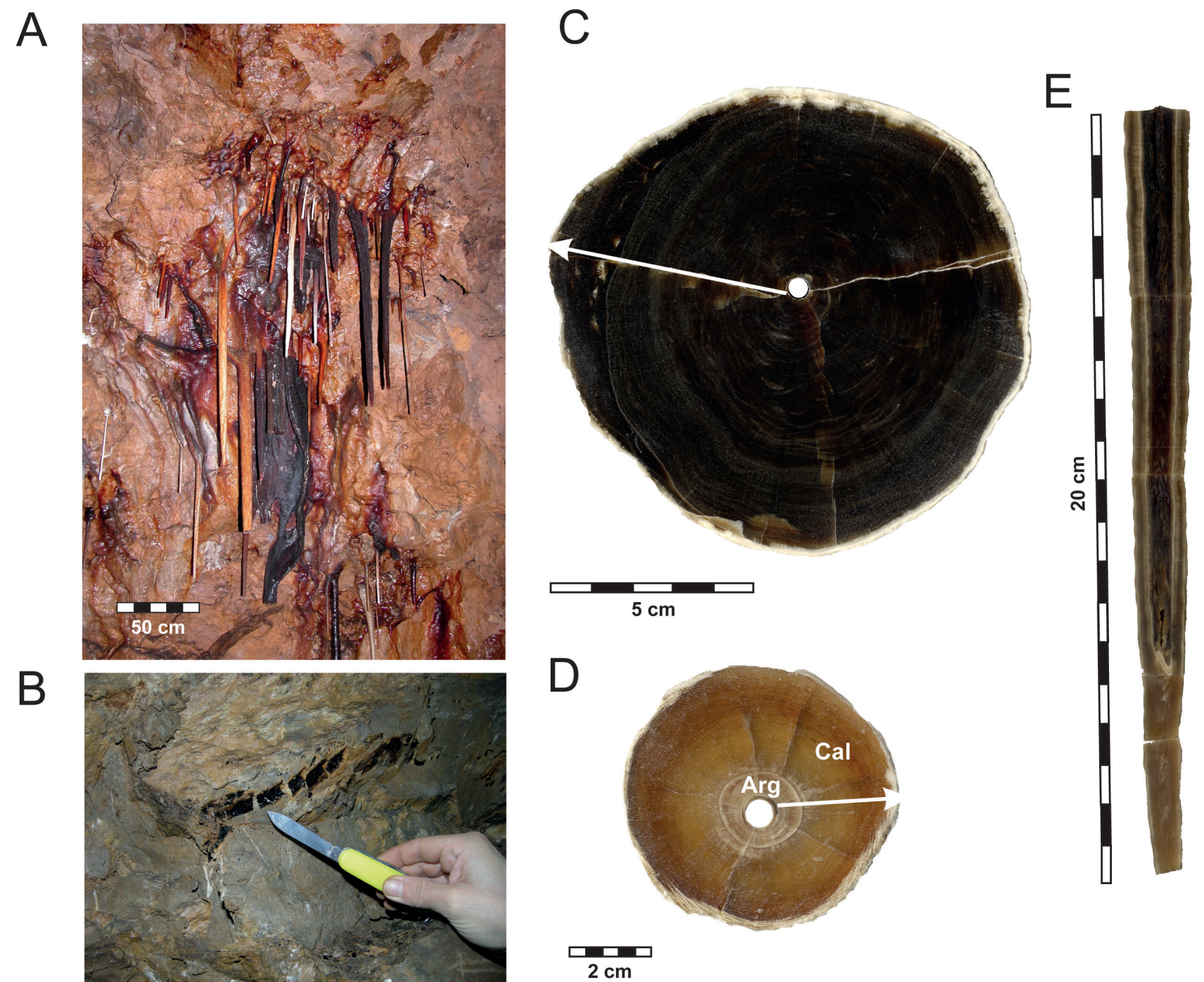

Figure 2. A. Formation of amberine stalactites in El Soplao Cave; B. Urgonian horizon of carbonaceous material and fusinites within the cave; C. Amberine stalactite sample SPLAMB-01; D. Amberine stalactite sample SPLAMB-02 with alternating layers of amberine calcite and aragonite; E. Amberine stalactite sample SPLAMB-03 with alternating layers of amberine calcite and aragonite. The arrows indicate the direction growth of the stalactites.

longitudinal section reveals alternating layers of calcite and aragonite (Fig. 2E).

The transition metals and rare earth elements that are typically chromophore are below the detection limit of the techniques employed in this work. Elements such as Ce, Sc, V, Pr, Nd, Sm, Eu, Gd, Tb, Dy, Ho, Er, Tm, Yb, and Lu appear below 0.01 ppm. Concentrations of $\mathrm{Fe}, \mathrm{Y}, \mathrm{Nb}, \mathrm{Ta}, \mathrm{Hf}, \mathrm{Tl}, \mathrm{Pb}$ and $\mathrm{Th}$, are lower than $0.1 \mathrm{ppm}$ whereas $\mathrm{Co}, \mathrm{Zn}$, and $\mathrm{Ni}$ are around 1 ppm (Gázquez et al., 2010).

Samples of Urgonian carbonaceous material were taken from the wall of the gallery containing the amberine speleothems (SPLMOC-01) (Fig. 2B and Fig. $6 \mathrm{~A}, \mathrm{~B})$, and from other sites in the cave, as well as from strata outcropping at surface close to the amber deposit (SPLMOC-02 and SPLMOC-03).

The organic matter was isolated from the powdered samples using a separation method based on acid digestion adapted from Ramseyer et al. (1997). Two samples weighing $5 \mathrm{~g}$ were extracted from two spots in stalactite SPLAMB-01 (near to the central canal and just below the outer whitish layer) and one from stalactite SPLAMB-02 (from the darker part). These were reacted with excess $\mathrm{HCl}(12 \mathrm{M})$ over 24 hours at ambient temperature, maintaining an acid $\mathrm{pH}$ in the solution. The solutions were neutralised with $\mathrm{NaOH}$ (1 M) and centrifuged. Later, the residues were rinsed several times in distilled water and finally dried. The extracts thus obtained were labelled as SPLMOC-04, SPLMOC-05, and SPLMOC-06.

\section{Spectroscopic and mineralogical analysis (FTIR and FT-Raman)}

Solid-state Fourier-transform infrared spectra (FTIR) of less than $0.5 \mathrm{mg}$ of each powdered sample (SPLMOC-01, SPLMOC-02, SPLMOC-05, SPLMOC-04, SPLMOC-05 and SPLMOC-06) were recorded on a Perkin Elmer Spectrum 100 FT-IR spectrometer in reflectance mode. Samples were scanned over the $550-4000 \mathrm{~cm}^{-1}$ range, with 25 iterations. Spectral resolution was $0.4 \mathrm{~cm}^{-1}$, wavelength precision, 0.008 $\mathrm{cm}^{-1}$ at $2000 \mathrm{~cm}^{-1}$, and wavelength accuracy, 0.02 at $2000 \mathrm{~cm}^{-1}$.

Raman spectroscopy analysis was performed using 
a FT-Raman Bruker instrument (model RFS100/S). The coherent laser was a Compass 1064-500 model (Nd:YAG, $1064 \mathrm{~nm}, 500 \mathrm{~mW}$ ). The CCD Bruker used was a D418-T model, operating in the range 851 $1695 \mathrm{~nm}$. The spot diameter was 100 micrometers, using a spectrometer aperture of $7 \mathrm{~mm}$ and a scanning velocity of $7.5 \mathrm{KHz}$. Spectral resolution was $4 \mathrm{~cm}^{-1}$. The obtained spectra were compared with the RRUFF Raman mineralogical database standard (http:// rruff.info/) for calcite and aragonite. Both techniques were carried out in the Unidad Asociada UVA-CSIC$\mathrm{CAB}$ of the University of Valladolid, Spain.

\section{RESULTS}

The stalactite sample SPLAMB-01 was identified as calcite by IR and Raman spectroscopy, both in the amberine calcite and the external whitish crust. In contrast, calcite and aragonite was detected in samples SPLAMB-02 and SPLAMB-03. In SPLAMB-02, aragonite was limited to the innermost layer, the two minerals occurred in alternating layers in SPLAMB-03. Signals other than calcite or aragonite were not identified in any of the carbonate samples.

IR signals appeared at 2923 and $2847 \mathrm{~cm}^{-1}$, both in the carbonaceous strata and in the stalactite extracts, except in sample SPLMOC-06. The wide signal at around $3403-3170 \mathrm{~cm}^{-1}$ is related to the stretching band of the $\mathrm{O}-\mathrm{H}$ water bond, due to the hygroscopic nature of the organic material. Subsamples extracted from the speleothems (SPLMOC-04, SPLMOC-05, and SPLMOC-06) produced intense, narrow signals at 594,670 , and $1094 \mathrm{~cm}^{-1}$. Signals between 1544-1643 $\mathrm{cm}^{-1}$ and between 1373 and $1436 \mathrm{~cm}^{-1}$ were detected in all samples, although in the carbonaceous strata samples there were also signals at around $1021 \mathrm{~cm}^{-1}$ (Fig. 3).

The amberine calcite in the speleothems (SPLAMB-01) produced Raman signals typical for calcite at $157,253,713$, and $1087 \mathrm{~cm}^{-1}$. In addition, there were weak signals at around 1021, 1301, 1705, 2852 , and $2885 \mathrm{~cm}^{-1}$. The carbonaceous sample of the stratum from inside the cave (SPLMOC-1) gave an intense signal around $1496 \mathrm{~cm}^{-1}$ and weaker, wider signals around 1696, 1621, 1592, 1318, 1273, and $1102 \mathrm{~cm}^{-1}$. Extract SPLMOC-4 produced an intense signal at $1496 \mathrm{~cm}^{-1}$ and weak Raman signals around $1656,1621,1465,1314,1266,1017$, and $925 \mathrm{~cm}^{-1}$ (Fig. 4). Unfortunately, due to the dark colour of these samples and their fluorescent nature, it was not possible to obtain good-quality Raman spectra for the remaining extracts. Finally, the white crust coating the speleothems shows typical peaks for calcite, in addition to the weak ones around 1021, 1444, 1497, and $1754 \mathrm{~cm}^{-1}$.

\section{DISCUSSION}

\section{Colour of the amberine speleothems}

The colouration of the amberine speleothems from El Soplao Cave is a singular case in the field of calcite speleothems. Our starting hypothesis pointed to leachates of organic compounds containing abundant fossilized plant remains (Fig. 5) from strata overlying
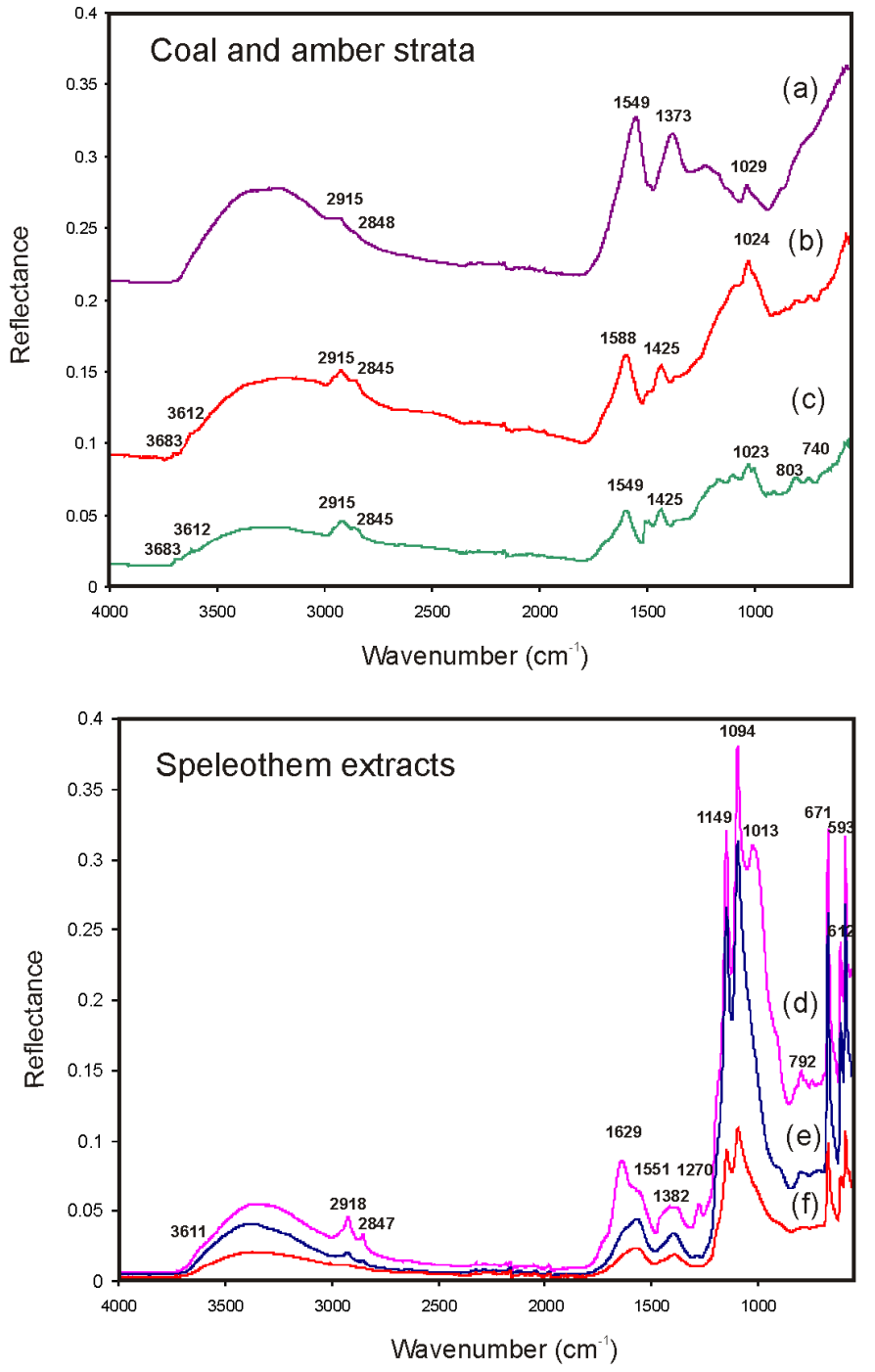

Figure 3. IR spectra of samples of carbonaceous materials and extracts of amberine speleothems from El Soplao Cave: (a) carbonaceous strata overlying speleothems (SPLMOC-01), (b) and (c) carbonaceous strata outcropping outside of the cave (SPLMOC-02 and SPLMOC-03), (d) and (e) extract of sample SPLAMB-01 (SPLMOC-04 and SPLMOC-05), (f) extract of sample SPLAMB-02 (SPLMOC-06).

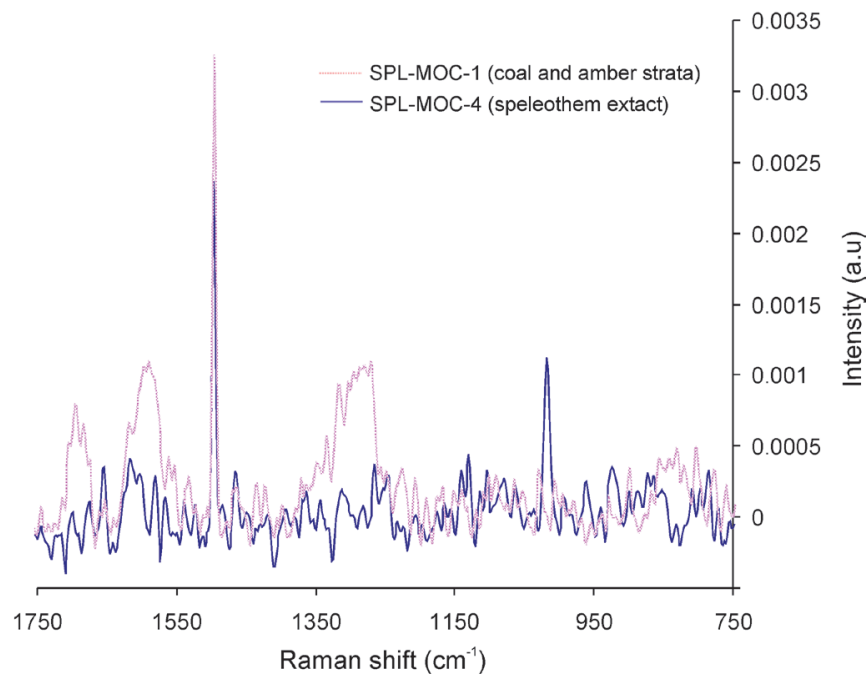

Figure 4. FT-Raman spectra of a coal sample from the Florida Formation (SPLMOC-1) and of an extract of organic material from an amberine stalactite (SPLMOC-4). 


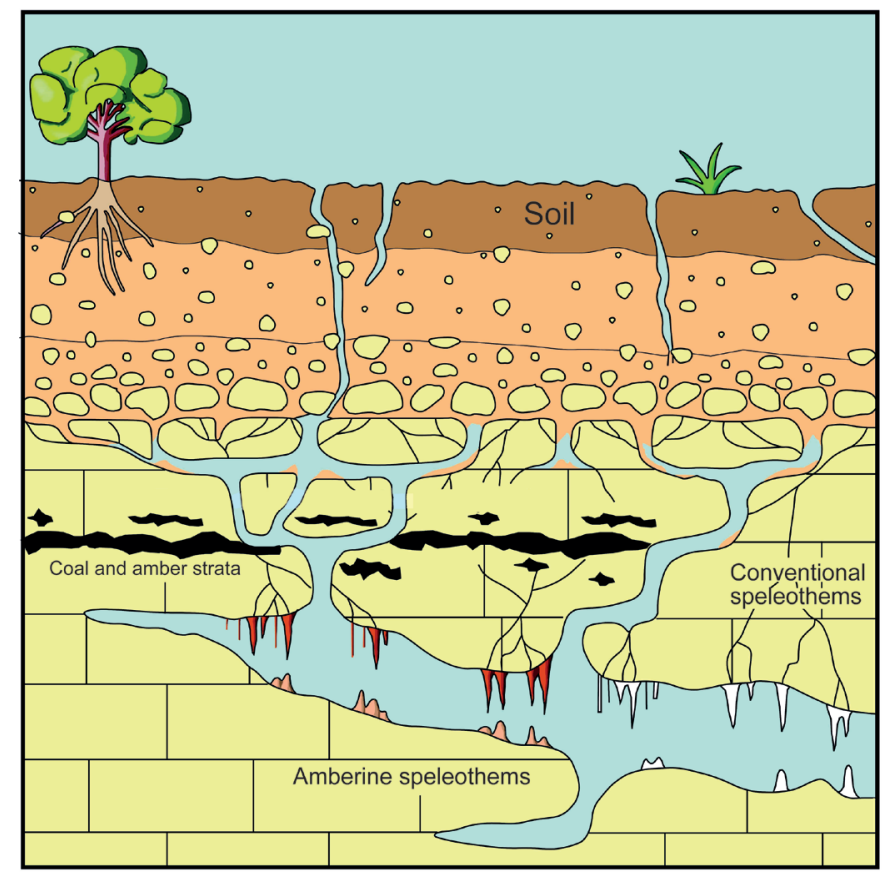

Figure 5. Conceptual scheme for the disposition of carbonaceous strata inside El Soplao Cave: The formation of amberine speleothems occurred beneath the Urgonian facies strata that contain abundant organic material and are associated with deposits of Cretaceous amber.

the cave, which are also visible at certain locations within the cave (Fig. 2B).

The IR spectra of the extracts obtained from the stalactites (SPLMOC-4, SPLMOC-5 and SPLMOC-6) are similar to each other and to samples of carbonaceous strata of the host rock (SPLMOC-1, SPLMOC-2 and SPLMOC-3; Fig. 3). Characteristic signals of organic compounds, such as those at 2923 and $2847 \mathrm{~cm}$ 1 , relate to aliphatic $\mathrm{C}-\mathrm{H}$ stretching appear in all samples except SPLMOC-6 (carbonaceous material at the ground surface). Likewise, the signals between 1544 and $1643 \mathrm{~cm}^{-1}$ are related to the presence of $\mathrm{C}=\mathrm{C}$ double bonds and $\mathrm{H}$ linked to $\mathrm{C}=\mathrm{O}$, which are typical of aromatic compounds. The signals in the $1373-1436 \mathrm{~cm}^{-1}$ range are due to symmetric stretching of the COO- functional group (Rosaleen et al., 2004). This pattern of functional groups coincides with mixing of fulvic and humic acids identified in previous work dealing with the spectroscopic signal of these compounds (Lebron \& Suárez, 1996; Yang \& Wang, 1997; Pospíšilová et al., 2008). Part of the residue recovered corresponds to silicate minerals (clays and quartz grains from the host rock) that were incorporated in the calcitic layers, as indicated by the signal at $1021 \mathrm{~cm}^{-1}$ in all the FTIR spectra observed.

The Raman spectra for the carbonaceous stratum (SPLMOC-1) and the speleothem extract (SPLMOC-4) are somewhat similar, which confirms their shared structural composition (Fig. 4). Well-defined signals around 1290 and $1592 \mathrm{~cm}^{-1}$ in the samples of the carbonaceous stratum correspond to bands D and G of the $\mathrm{C}-\mathrm{C}$ bond, respectively. These signals have been previously identified in graphite, weathered coal, and in humic acids from natural waters (Yang \& Wang,
1997). The narrow, intense signal around $1496 \mathrm{~cm}^{-1}$ is unequivocally due to the $\mathrm{C}-\mathrm{H}$ stretch vibration and the $\mathrm{C}-\mathrm{H}$ bending vibration (Yang \& Wang, 1997). In the sample of amberine speleothem extract, the same intense signal at $1496 \mathrm{~cm}^{-1}$ is clear, whilst the signal at $1592 \mathrm{~cm}^{-1}$ is slightly weaker, revealing the presence of C-C bonds.

Due to the high $\mathrm{SO}_{4}{ }^{2-}$ concentration in the stalactites (up $10.000 \mathrm{ppm}$ in some spots analyzed by electron microprobe) (Gázquez et al., 2010), sulphate minerals (bassanite and gypsum) were precipitated during the extraction of organic material. As a result, signals were recorded at 594, 670, and $1094 \mathrm{~cm}^{-1}$, corresponding to vibrations of the S-O bond in the $\mathrm{SO}_{4}{ }^{2-}$ (Berenblut et al., 1971). Meanwhile, the wide, ill-defined signal that peaks around $3403-3170 \mathrm{~cm}^{-1}$ is related to the stretching band of the $\mathrm{O}-\mathrm{H}$ bond of the water hygroscopically attached to the organic material, and due to structural water of gypsum and bassanite formed during the drying phase of sample preparation. Noteworthy is another well-defined Raman signal in this extract at $1017 \mathrm{~cm}^{-1}$, which relates to the principal vibration $\left(\mathrm{u}_{1}\right)$ of the $\mathrm{SO}_{4}^{2-}$ (Takahashi et al., 1983), suggesting the presence of residual sulphate precipitated during the sample preparation and treatment.

In general, high-grade coal (anthracite) includes few $\mathrm{C}=\mathrm{O}$ groups or isolated $\mathrm{C}=\mathrm{C}$ bonds, and it lacks triple bonds. The presence of carbonyl and carboxyl groups is usually due to lignin, derived from the vegetation that formed the coal, which is easily oxidised (Hatcher et al., 1990). During the early stage of coalification, the decayed organic material of higher plants is condensed into humic acid-like substances (del Río et al., 1994). Data suggest that the low-grade coal present in the Florida Formation is the precursor of the humic and fulvic acids found in the amberine speleothems. Evidence of low-grade metamorphism is also suggested by the existence of well-preserved fossilised pollen grains in the coal strata (Fig. 6C). Small differences found between the samples analysed could be due to variations in the degree of maturation of the fossilised organic material.

The microcrystalline texture observed in the amberine calcite of these speleothems accords with their high organic content. The layers of calcite are formed by crystals with numerous defects that usually reflects a variable water flow and the presence of growth inhibitors (Frisia et al., 2000). The inhibitory effect of organic material on the growth of the calcite was tested by Lebron \& Suárez (1996) who showed that when the concentration of organic compounds in the water is high, the growth rate decreases. As a result, incorporation of organic compounds, even of large size, is favoured. This phenomenon is the cause of the characteristic dark colouration of the amberine speleothems.

Although Richter et al. (2004) demonstrated that the presence of rare earth elements and $\mathrm{Mn}^{2+}$ related to high infiltration events can produce colouration in calcite speleothems, the analytical techniques 

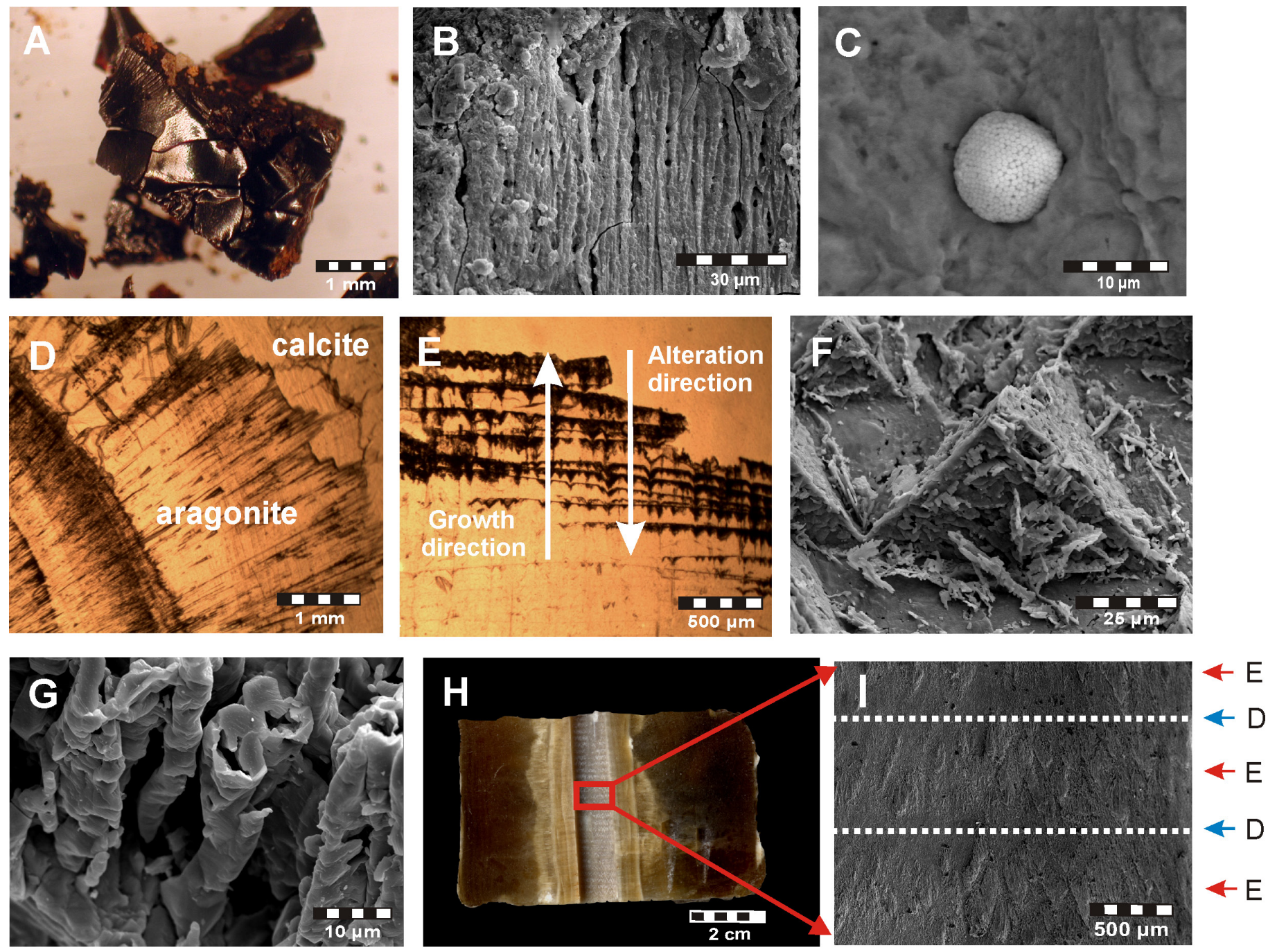

Figure 6. A. Urgonian carbonaceous material of the Florida Formation in El Soplao Cave; B. Woody veins of fossilized wood that are the precursor of coal in El Soplao; C. Fossilized pollen grain in the coal; D. Contact between aragonite and amberine calcite layers in sample SPLAMB-02; E. Alternating layers of amberine calcite due to precipitation of moonmilk; F. Subeuhedral calcite crystals in the outer layers of altered amberine calcite affected by dissolution and re-precipitation; G. Biogenic calcite in the outer layers of altered amberine calcite; $\mathrm{H}$. Longitudinal section of sample SPLAMB-02 showing the core of aragonite enveloped by amberine calcite; I. Alternation of light and dark layers in the central canal of stalactite SPLAMB-03. The E layers (formed through degassing and evaporation) exhibit a relief that causes slight narrowing of the orifice, whilst the surface of the $D$ layers (formed mostly by degassing of CO2) is smooth.

employed in the present study mean that chromophore elements can be excluded as the cause of the strong dark colour of the stalactites examined. In the case of the amberine speleothems from El Soplao Cave, mobilization of fulvic and humic acid from Urgonian carbonaceous strata has been identified as the mechanisms that coloured these rare speleothems.

\section{Evolutionary mechanism and palaeoenvironmental implications}

The evolution of the amberine stalactites examined was clearly polyphasic and controlled by the El Soplao Cave microclimate over their period of formation. Three main periods can be distinguished. During the first, conditions favoured formation of an aragonite soda straw. In the second phase, amberine calcite was precipitated, rich in organic compounds that were the precursors of the characteristic colouration of these speleothems. Most recently, in an on-going process, a crust of white calcite that lacks chromophore organic compounds has formed.
Initially, the environment under which speleothems developed was characterized by restricted movement of the air masses (Fig. 7A). These conditions led to relatively high humidity, high $\mathrm{CO}_{2}$ partial pressure, and low evaporation rates. As a result, the degree of oversaturation of the solution and the nucleation rate were low. Under conditions of near-equilibrium in terms of saturation, precipitation of aragonite is favoured over that of calcite (Frisia et al., 2002). It is also worth noting that the high concentration of $\mathrm{Mg}$ inhibited nucleation of calcite (Bischoff \& Fyfe, 1968; Burton \& Walter, 1987). Frisia et al. (2002) identified an inverse relationship between the $\mathrm{Mg} / \mathrm{Ca}$ ratio and the drip rate, which suggests that slow drip rate and high saturation can cause aragonite precipitation. The saturation state could be increased by enhanced dissolved inorganic carbon in dripwater, due to increased sulphide oxidation of the minerals in the surrounding host rock.

In the amberine speleothems, the first acicular crystals of aragonite were precipitated around 
water drops on the roof of the cave, in a similar process to that responsible for the precipitation of aragonite eccentrics that cover large parts of the roof and walls of the cave (Gázquez et al., 2011). The crystalline structure of the aragonite does not allow coprecipitation of many organic molecules (Ramseyer et al., 1997), which explains why the aragonite layers lack colouration.

The structure of the aragonite crystals is acicular, and it forms elongated conical aggregates. If the drip rate is sufficiently high, the diameter of the tube tends to increase gradually, as the acicular crystals grow (Fig. 7B). Since this process is relatively slow, the aragonite acicular crystals grow around the water drop. Capillarity means that the drop is generated at the tip of the longest needles, so that growth is directed away from the centre of the tube (Fig. 7C). As a consequence, the diameter of the tube increases and the morphology of the stalactite as well, leading to a wavy aspect of the speleothems surface.
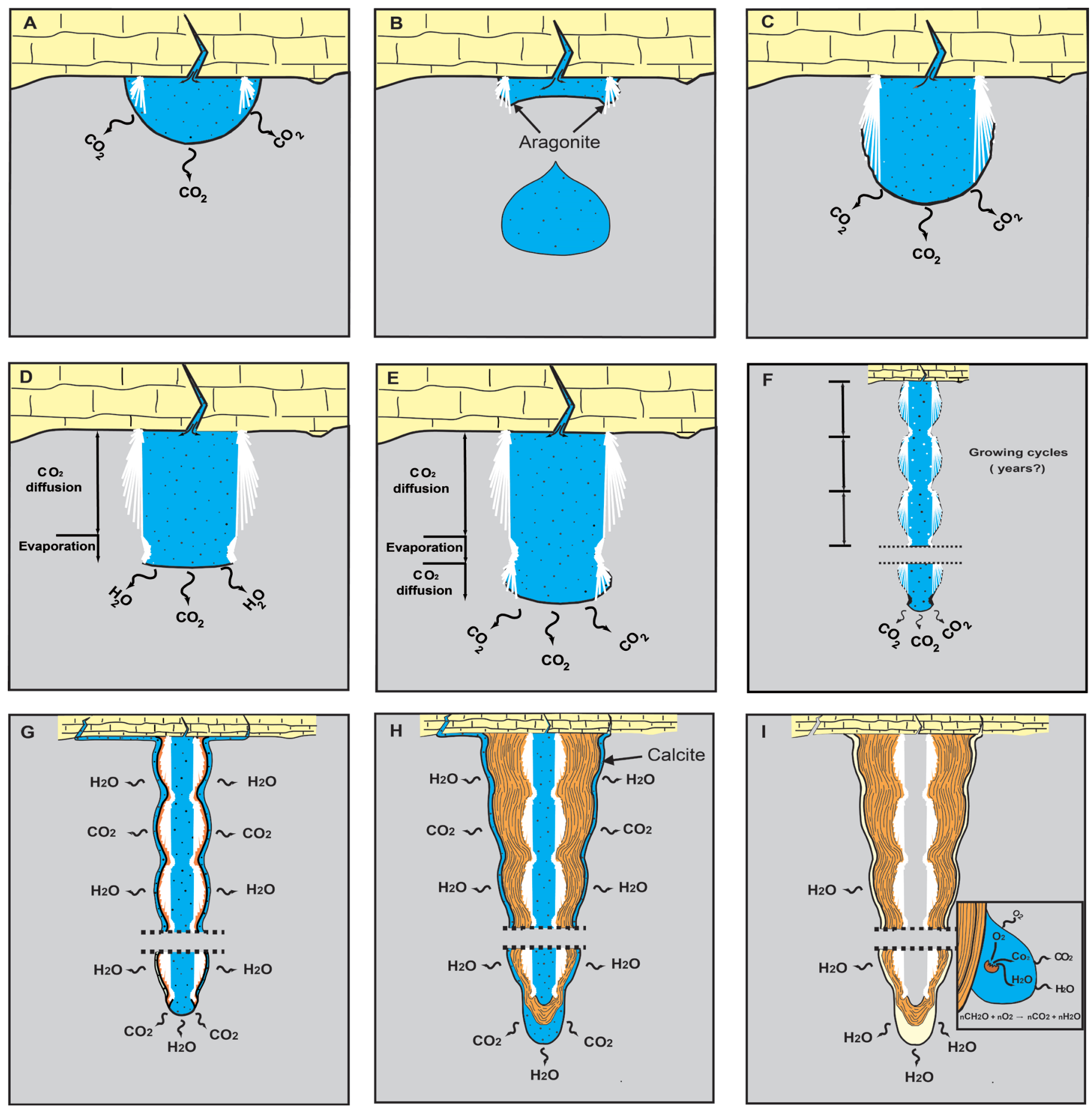

Figure 7. Sketches showing the genesis of amberine stalactites in El Soplao Cave: A. Precipitation of aragonite needles around a drop on the roof of the cave due to diffusion of $\mathrm{CO}_{2}$; B. A falling drop leaves the central canal free; C. Growth of acicular aragonite crystals along c-axis; D. Precipitation of aragonite by diffusion of $\mathrm{CO}_{2}$ and evaporation; E. Precipitation of aragonite due to diffusion of $\mathrm{CO}_{2} ; \mathrm{F}$. The aragonite sodastraw is precipitated as cycles of diffusion and evaporation alternate; G. Superficial flow over the amberine speleothems; $\mathrm{H}$. Precipitation of amberine calcite; I. Precipitation of moonmilk and degradation of organic compounds causes an increase in the acidity of the microenvironment triggering the decay of speleothems. 
Seasonally, the rate of water supply falls and the drip rate decreases; the process of evaporation is activated and may even become dominant. As a result, oversaturation and rate of nucleation increase (as well as the $\mathrm{Mg} / \mathrm{Ca}$ ratio) and the diameter of the tube narrows slightly (Fig. 7D). When the water supply is re-established, the process of diffusion again dominates over that of evaporation and the degree of oversaturation decreases: the size of the aragonite needles increases and the orifice gets bigger (Fig. 7E). It is clear that in El Soplao, the rate of evaporation oscillated cyclically. The alternating cycles of diffusion and evaporation were probably determined by seasonal factors, as suggested by the orderly succession and dimensional constancy of these coupled-layers along the length of the tube (Fig. 6H, and Fig. 6I). Alternation of coupled layers in speleothems has been related to annual cycles (Finch et al., 2001; Baker et al., 2003; McMillan et al., 2005), or to periodic ones (Finch et al., 2001; Treble et al., 2003) similar to those that occurred in the amberine speleothems.

At a certain stage in the cave's evolution, the composition of the drip water changed and the level of dissolved inorganic carbon in the water increased considerably. This was probably caused by an increase in the rate of dissolution of the host rock due to acidification liked to oxidation of sulphides in the formation. Consequently, oversaturation increased when water in the cave started to degasify. Under such conditions, calcite precipitation was favoured and layers of this mineral precipitated over the surface of the soda-straw (Fig. $7 \mathrm{G}$ ).

In addition, a change in the outside environment towards wetter conditions, took place during the precipitation phase of the amberine calcite, as deducted from the presence of stalactites lacking internal aragonite tubes. This indicates that calcite precipitation was a consequence of increased infiltration into El Soplao Cave, possibly caused by wetter conditions at surface. In this relatively humid period, precipitation of amberine calcite was favoured over aragonite (which is usually an indicator of relative aridity in caves; Finch et al., 2001; Frisia et al., 2002). Precipitation of calcite was almost constant along the whole length of the speleothems (Fig. 2D). Thus, the speleothems grew lengthwise, whilst their diameter remained relatively narrow. This process allows us to propose that thee external surface in the form of rings was determined by the original structure of the central aragonite soda-straw (Fig. 7H). During this phase, the central canal of many of the stalactites narrowed and even closed completely locally, so that growth of the stalactite became mostly superficial.

The outermost layer of the amberine stalactites has a different colour compared to the rest of the speleothem. This external layer is deposited over clearly altered layers of amberine calcite (Fig. 6E). These alterations let see subeuhedral calcite crystals (Fig. 6F), alternating with others of a markedly biogenic nature (Fig. 6G). Probably, when the mining galleries intercepted the cave during the last century, the conditions in the vadose zone were disrupted. Consequently, the water flow on the speleothems diminished dramatically due to decreasing air humidity. This is why the amberine stalactites are inactive at present. Nevertheless, the surface of the speleothems continued to be wet and slowly, they became covered in a layer of calcite moonmilk of biological origin, as demonstrated by the presence of like-biological structures in this layer (Fig. 6I and Fig. 7I). This type of alteration is frequent in speleothems and is often related to microbial activity (Northup \& Lavoie, 2001).

It is proposed that, during the process of alteration, fulvic and humic acids trapped in calcite came into contact with the cave atmosphere and were oxidised to $\mathrm{CO}_{2}$, thus preventing further chromatic effects on the newly-deposited moonmilk. The excess $\mathrm{CO}_{2}$ could have been the main factor responsible for additional dissolution of the amberine layers (Fig. 6E). We consider that the presence of organic matter (fulvic and humic acids) may be also a source of food for these bacteria (Fig. 7I).

Opening of the mine triggered changes in the ventilation regime of the natural galleries, and this may have led to colonization of the surface of the stalactites by allocthonous bacteria. On the other hand, it could simply be that the newly oxygenated environment, and the temperature changes produced as a result of the mining exploitation, favoured the activity of microorganisms already present in the cave to flourish.

\section{CONCLUSIONS}

The strong dark colour of the El Soplao amberine speleothems is not related to the presence of chromophore trace elements, but to organic material derived from Cretaceous strata rich in fossil organic material, and to locally-abundant quantities of amber. Raman and IR spectroscopy analyses on the carbonaceous material in the bedrock and material extracted from the stalactites demonstrate that the compounds responsible for their colouration are humic and fulvic acids derived from the carbonate strata. This formation is the first reported evidence of such a source of organic matter in speleothems. We suggest that future research should investigate the contribution of the host rocks and interlayer coal strata to the presence of organic compounds in speleothems.

The mineralogy of the amberine speleothems indicates that significant changes occurred in the subterranean environment of El Soplao Cave. Precipitation of aragonite was related to relatively dry periods that increased the $\mathrm{Mg} / \mathrm{Ca}$ ratio in the drip water. In contrast, under the more humid conditions oxidation of sulphide minerals was favoured. The increase in dissolved inorganic carbon in the water could have caused precipitation of amberine calcite, but at a relatively low growth rate because of the presence of organic compounds. Lastly, the precipitation of moonmilk over the surface of the 
speleothems led to the alteration of the outer layers of amberine calcite by bacteria produced $\mathrm{CO}_{2}$ that degraded the organic material that had been trapped in the speleothems.

\section{ACKNOWLEDGEMENTS}

The authors are grateful for support of Esmeralda Urea, SEM facility of Servicios Centrales de Investigacion of the University of Almeria. We are grateful to Aurelio Sansano, the technician who performed the Raman analyses. We would also like to thank the management of El Soplao S.L. for allowing us to use their facilities and providing access to the cave. Financial support was made available through the "PALEOGYP" International Collaboration Project (CGL2006-01707/BTE Ministry of Science and Innovation, Spain), the Spanish Science Grant AP2007-02799 and the funds of the Water Resources and Environmental Geology Research Group (University of Almeria). We thank Bogdan P. Onac and an anonymous reviewer for helpful suggestions. Special thanks to Fermin Unzué, manager of the El Soplao in the year of his retirement, for his great help and enthusiasm to the project of knowledge of this marvelous cave.

\section{REFERENCES}

Baker A., Smart P.L., Edwards R. \& Richards D., 1993 - Annual growth banding in a cave stalagmite. Nature, 364: 518-520. http://dx.doi.org/10.1038/364518a0

Baker A., Barnes W.L. \& Smart P.L., 1996 - Speleothem luminescence intensity and spectral characteristics: Signal calibration and a record of palaeovegetation change. Chemical Geology, 130 (1-2): 65-76. http://dx.doi.org/10.1016/0009-2541(96)00003-4

Baker A. \& Genty D., 2003 - Comment on "a test of annual resolution in stalagmites using tree rings". Quaternary Research, 59 (3): 476-478.

http://dx.doi.org/10.1016/S0033-5894(03)00038-3

Berenblut B.J., Dawson P. \& Wilkinson G.R., 1971 The Raman spectrum of gypsum. Spectrochimica Acta A, 27 (9): 1849-1863. http://dx.doi.org/10.1016/0584-8539(71)80238-6

Bischoff J.L. \& Fyfe W.S., 1968 - Catalysis, inhibition, and the calcite-aragonite problem. I. The aragonite-calcite transformation. American Journal of Science, 266: 65-79. http://dx.doi.org/10.2475/ajs.266.2.65

Blyth A.J., Asrat A., Baker A., Gulliver P., Leng M.J. \& Genty D., 2007- A new approach to detecting vegetation and land-use change using high-resolution lipid biomarker records in stalagmites. Quaternary Research, 68 (3): 314-324. http://dx.doi.org/10.1016/j.yqres.2007.08.002

Blyth A.J., Baker A., Collins M.J., Penkman K.E.H., Gilmour M.A., Moss J.S., Genty D. \& Drysdale R.N., 2008 - Molecular organic matter in speleothems and its potential as an environmental proxy. Quaternary Science Reviews, 27 (9-10): 905-921. http://dx.doi.org/10.1016/j.quascirev.2008.02.002
Burton E.A. \& Walter L.M., 1987 - Relative precipitation rates of aragonite and $\mathrm{Mg}$ calcite from seawater: temperature or carbonate ion control? Geology, 15: 111-114.

http://dx.doi.org/10.1130/00917613(1987) 15<111:RPROAA > 2.0.CO;2

Caldwell J., Davey A.G., Jennings J.N. \& Spate A.P., 1982 - Colour in some Nullarbor Plain speleothems. Helictite, 20: 3-10.

Crowell B.E. \& White W.B., 2012 - Measurement of luminescent banding in speleothems: some techniques and limitations. International Journal of Speleology, 41 (1): 51-58.

http://dx.doi.org/10.5038/1827-806X.41.1.6

del Río J.C., González-Vila F.J., Martín F. \& Verdejo T., 1994 - Characterization of humic acids from low-rank coals by ${ }^{13} \mathrm{C}-N M R$ and pyrolysis-methylation. Formation of benzenecarboxylic acid moieties during the coalification process. Organic Geochemistry, 22 (6): 885-891. http://dx.doi.org/10.1016/0146-6380(94)90026-4

Fairchild I.J. \& Hatland, A. 2010 - Trace element variations in stalagmites: controls by climate and by karst system processes. EMU Notes in Mineralogy, 10 (7): 259-287.

Finch A.A., Shaw P.A., Weedon G.P. \& Holmgren K., 2001 - Trace element variation in speleothem aragonite: potential for palaeoenvironmental reconstruction. Earth and Planetary Science Letters, 186 (2): 255-267. http://dx.doi.org/10.1016/S0012-821X(01)00253-9

Frisia S., Borsato A., Fairchild I. \& McDermott F., 2000 - Calcite fabrics, growth mechanisms, and environments of formation in speleothems from the Italian Alps and Southwestern Ireland. Journal of Sedimentary Research, 70: 1183-1196. http://dx.doi.org/10.1306/022900701183

Frisia S., Borsato A., Fairchild I.J., McDermott F. \& Selmo E.M., 2002 - Aragonite-calcite relationships in speleothems (Grotte de Clamouse, France): environment, fabrics and carbonate geochemistry. Journal of Sedimentary Research, 72: 687-699. http://dx.doi.org/10.1306/020702720687

Gázquez F., Delgado-Huertas A., Forti P., Stöll H. \& Calaforra J.M., 2010 - Los espeleotemas ambarinos de la Cueva de El Soplao (Cantabria) In: Durán, J.J. \& Carrasco, F. (Eds.), Cuevas: Patrimonio, Naturaleza, Cultura y Turismo. Madrid: Asociación española de cuevas turísticas.

Gázquez F., Calaforra J.M., Forti P., 2011 Black Mn-Fe Crusts as Markers of Abrupt Palaeoenvironmental Changes in El Soplao Cave (Cantabria, Spain). International Journal of Speleology, 40(2): 163-169. http://dx.doi.org/10.5038/1827-806X.40.2.8

Hatcher P.G., 1990 - Chemical structural models for coalified wood (vitrinite) in low rank coal. Organic Geochemistry, 16 (4-6): 959-968. http://dx.doi.org/10.1016/0146-6380(90)90132-J 
IGME 1976 - Mapa geológico de España E 1: 50000. Hoja 57. Cabezón de la Sal.

Lead J.R. \& Wilkinson K.J., 2006 - Aquatic colloids and nanoparticles: Current knowledge and future trends. Environmental Chemistry, 3: 159-171. http://dx.doi.org/10.1071/EN06025

Lebron I. \& Suarez D.L., 1996 - Calcite nucleation and precipitation kinetics as affected by dissolved organic matter at $25^{\circ} \mathrm{C}$ and $\mathrm{pH}>7.5$. Geochimica et Cosmochimica Acta, 60 (15): 2765-2776.

http://dx.doi.org/10.1016/0016-7037(96)00137-8

López-Cilla I., Rosales I., Najarro M., Martín-Chivelet J., Velasco F. \& Tornos F., 2009 - Etapas de formación de dolomías masivas del entorno de La Florida-El Soplao, Cantabria. Geogaceta, 47: 65-68.

López-Horgue M.A., Owen H.G., Aranburu A., Fernández-Mendiola P.A. \& García-Mondéjar J., 2009 - Early late Albian (Cretaceous) of the central region of the Basque-Cantabrian Basin, northern Spain: biostratigraphy based on ammonites and orbitolinids. Cretaceous Research, 30 (2): 385-400. http://dx.doi.org/10.1016/j.cretres.2008.08.001

Martínez-Ruíz F., Ortega-Huertas M. \& Rivas P., 2006 - Rare earth element composition as evidence of the precursor material of Cretaceous-Tertiary boundary sediments at distal sections. Chemical Geology, 232 (1-2): 1-11.

McGarry S.F. \& Baker A., 2000 - Organic acid fluorescence: applications to speleothem palaeoenvironmental reconstruction. Quaternary Science Reviews, 19 (11): 1087-1101. http://dx.doi.org/10.1016/S0277-3791(99)00087-6

McMillan E.A., Farichild I.J., Frisia S., Borsato A. \& McDermott F., 2005 - Annual trace element cycles in calcite-aragonite speleothems: evidence of drought in the western Mediterranean 1200-1100 yr BP. Journal of Quaternary Science, 20 (5): 423433.

http://dx.doi.org/10.1002/jqs.943

Menor-Salván C., Najarro M., Velasco F., Rosales I., Tornos F. \& Simoneit B.R.T., 2010 - Terpenoids in extracts of Lower Cretaceous ambers from the Basque-Cantabrian Basin (El Soplao, Cantabria, Spain): Paleochemotaxonomic aspects. Organic Geochemistry, 41 (10): 1089-1103.

http://dx.doi.org/10.1016/j.orggeochem.2010.06.013

Najarro M., Peñalver E., Rosales I., Pérez-De la fuente R.\& Daviedo-Gómez V., 2009 - Unusual concentration of Early Albian arthropod-bearing amber in the Basque-Cantabrian Basin (El Soplao, Cantabria, Northern Spain): Palaeoenvironmental and palaeobiological implications. Geol. Acta., 7 (3): 363-387.

Northup D.E. \& Lavoie K.H., 2001 - Geomicrobiology of Caves: A Review. Geomicrobiology Journal, 18: 199-222.

http://dx.doi.org/10.1080/01490450152467750

Perrette Y., Poulenard J., Saber A., Fanget B., Guittonneau S., Ghaleb B. \& Garaudee S., 2008 - Polycyclic Aromatic Hydrocarbons in stalagmites: Occurrence and use for analyzing past environments. Chemical Geology, 251 (1-4): 67-76. http://dx.doi.org/10.1016/j.chemgeo.2008.02.013
Pospíšilová L., Fasurová N., Barančíková G. \& Liptaj T., 2008 - Spectral characteristics of humic acids isolated from south Moravian lignite and soils. Petroleum \& Coal, 50 (2): 30-36.

Quesada S., Robles S. \& Rosales I., 2005 - Depositional architecture and transgressive-regressive cycles within Liassic backstepping carbonates ramps in the Basque-Cantabrian Basin, N Spain. Journal of the Geological Society of London, 162: 531548

http://dx.doi.org/10.1144/0016-764903-041.

Railsback L.B., Brook G.A., Chen J., Kalin R. \& Fleisher C.J., 1994 - Environmental controls on the petrology of a late Holocene speleothem from Botswana with annual layers of aragonite and calcite. Journal of Sedimentary Research, 64: $147-155$.

Ramseyer K., Miano T.M., D’orazio V., Wildberger A., Wagner T. \& Geister J., 1997 - Nature and origin of organic matter in carbonates from speleothems, marine cements and coral skeletons. Organic Geochemistry, 26 (5-6): 361-378. http://dx.doi.org/10.1016/S0146-6380(97)00008-9

Richter, D.K., Götte, T., Niggemann, S. \& Wurth, G., 2004. - $\mathrm{REE}^{3+}$ and $\mathrm{Mn}^{2+}$ activated activated cathodoluminescence in lateglacial and Holocene stalagmites of central Europe: evidence for climatic processes? The Holocene. 14: 759-767. http://dx.doi.org/10.1191/0959683604hl754rp

Rosaleen J.A., Bendell D.J. \& Groundwater P.W., 2004 - Organic Spectroscopy Analysis. Royal Society of Chemistry, Cambridge, 28.

Shopov Y.Y., 2004 - Activators of luminescence in speleothems as source of major mistakes in interpretation of luminescent paleoclimatic records. International Journal of Speleology, 33 (1/4): 25-33.

http://www.ijs.speleo.it/pdf/61.517.33 Shopov activators.pdf

Shopov Y.Y., Ford D.C. \& Schwarcz H.P., 1994 Luminescent microbanding in speleothems: high resolution chronology and palaeoclimate. Geology, 22: 407-410.

Takahashi H., Maehara I. \& Kaneko N., 1983 - Infrared reflection spectra of gypsum. Spectrochimica Acta, 39 (5): 449-455.

http://dx.doi.org/10.1016/0584-8539(83)80160-3

Treble P.C., Chappell J. \& Shelley J.M.G., 2005 Complex speleothem growth processes revealed by trace element mapping and scanning electron microscopy of annual layers. Geochimica et Cosmochimica Acta, 69 (20): 4855-4863. http://dx.doi.org/10.1016/j.gca.2005.06.008

van Beynen P., Bourbonniere R., Ford D. \& Schwarcz H., 2001 - Causes of colour and fluorescence in speleothems. Chemical Geology, 175 (3-4): 319341.

http://dx.doi.org/10.1016/S0009-2541(00)00343-0

White W.B, 1997 - Colour of Speleothems In: Hill, C.A. \& Forti, P., (Eds.), Cave Minerals of the World. National Speleological Society, Huntsville. 
Xie S., Yi Y., Huang J., Hu C., Cai Y., Collins M. \& Baker A., 2003 - Lipid distribution in a subtropical southern China stalagmite as a record of soil ecosystem response to paleoclimate change. Quaternary Research, 60 (3): 340-347. http://dx.doi.org/10.1016/j.yqres.2003.07.010
Yang Y. \& Wang T., 1997 - Fourier transform Raman spectroscopic characterization of humic substances. Vibrational Spectroscopy, 14 (1): 105112.

http://dx.doi.org/10.1016/S0924-2031(96)00044-6 